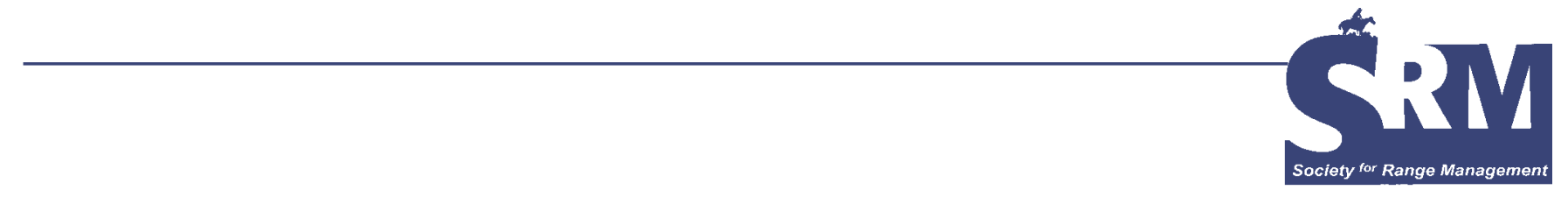

\title{
Chihuahua's Cattle Industry and a Decade of Drought: Economical and Ecological Implications
}

\section{By Carlos Ortega-Ochoa, Carlos Villalobos, Javier Martínez-Nevárez, Carlton M. Britton, and Ronald E. Sosebee}

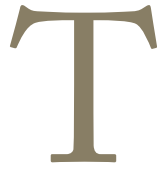

he state of Chihuahua is in northern México, with $798 \mathrm{~km}$ (496 miles) of common border with southern Texas and New Mexico. México's largest state, Chihuahua, covers $247,200 \mathrm{~km}^{2}$ $(610,845$ acres; Fig. 1$)$ that can be divided into three welldefined geographic areas. On the western edge is the mountainous region that is a part of the Sierra Madre, known as Sierra Tarahumara. Here altitude varies from $198 \mathrm{~m}$ (650 feet) in the barrancas ("deep ravines") to $3,050 \mathrm{~m}$ $(10,007$ feet $)$ at the mountain peaks. Rainfall averages about $660 \mathrm{~mm}$ (26.0 inches). Centrally located are the grasslands of the Mexican high plains extending into the state

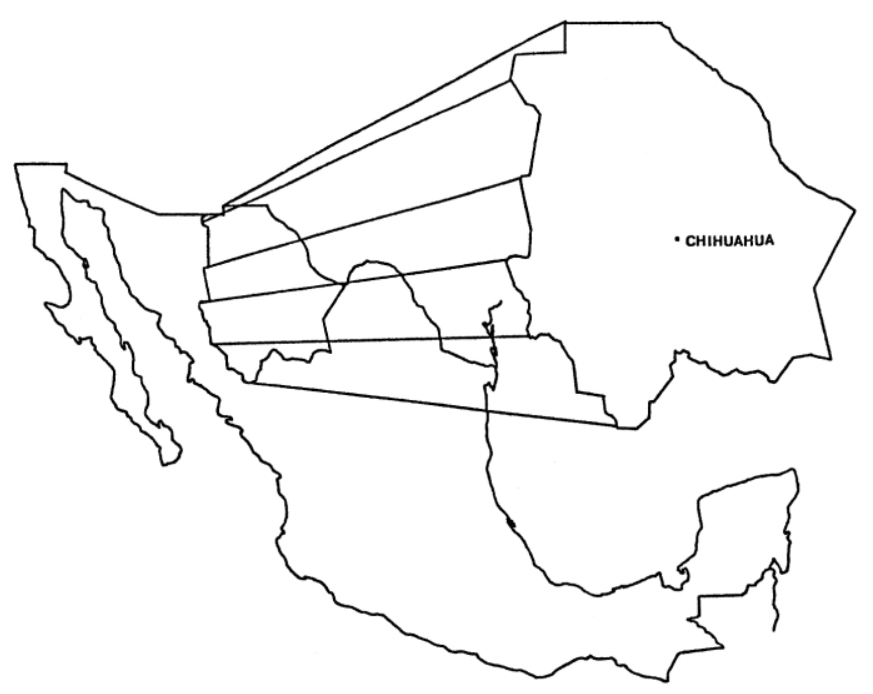

Figure 1. Location of the Mexican state of Chihuahua. of Chihuahua. Average annual rainfall ranges between $310 \mathrm{~mm}$ and $480 \mathrm{~mm}(12.2-19.0$ inches $)$ and lies between $1,220 \mathrm{~m}$ and $1,830 \mathrm{~m}(4,000-6,000$ feet $)$ above sea level. The state of Chihuahua also includes parts of North America's largest desert, the Chihuahuan Desert, with an average annual rainfall of less than $310 \mathrm{~mm}$ (12 inches) that produces the region's characteristic sparse vegetation.

In Chihuahua, land organization is based on private ranches and community-owned lands. Sixty-one percent of the state of Chihuahua territory is held by private ranchers, while $39 \%$ is communally owned. ${ }^{1}$ Communal lands are referred to as ejidos, a term also used to denote communal lands of the pre-Hispanic period that could not be rented, sold, or used as collateral. In 1992 México reformed its famous revolutionary Article 27 of the Constitution, which paved the way for redistributive agrarian reform and led to the creation of a social property sector consisting of ejidos and agrarian communities, where members would hold land in usufruct. The 1992 reform allegedly sought to enhance tenure security through certification and provide for privatization of communal lands with the expectation that this would invigorate México's agrarian productivity. ${ }^{2}$

Cattle, along with mining and forestry, are the foundation of the state's economy. In the state of Chihuahua, livestock are raised on 17.8 million ha $(68,726$ square miles) or $72 \%$ of the state's land area (Fig. 2). Beef cattle production is the most significant segment of the industry, comprising about $60 \%$ of the total livestock numbers. Cow/calf production is the most common ranching activity, but stocker operations and rodeo cattle are increasing in importance. Cow/calf and stocker operations are mostly located in 


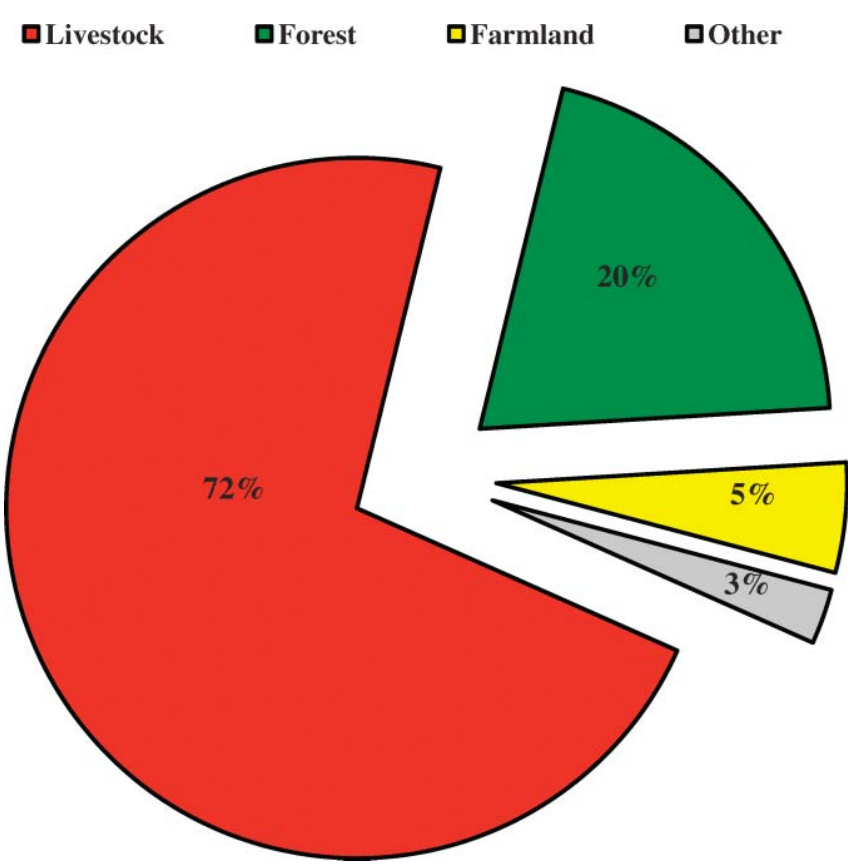

Figure 2. Land use in Chihuahua, México.

the arid, semiarid, and high plains regions of Chihuahua. Production of rodeo cattle is centered in western Chihuahua's mountainous region. Cull cows and bulls are usually kept for local consumption while young cattle are primarily exported to markets in the United States. Cattle from Chihuahua account for nearly $30 \%$ of the total cattle exported from México to the United States annually.

Most cattle in Chihuahua are produced on native rangelands that are totally dependent on rainfall. For northern México and the southwestern United States, the decade of the 1990s was characterized by a long-term drought. Periodic drought is common to rangelands around the world, ${ }^{3}$ but severity and duration can vary greatly.

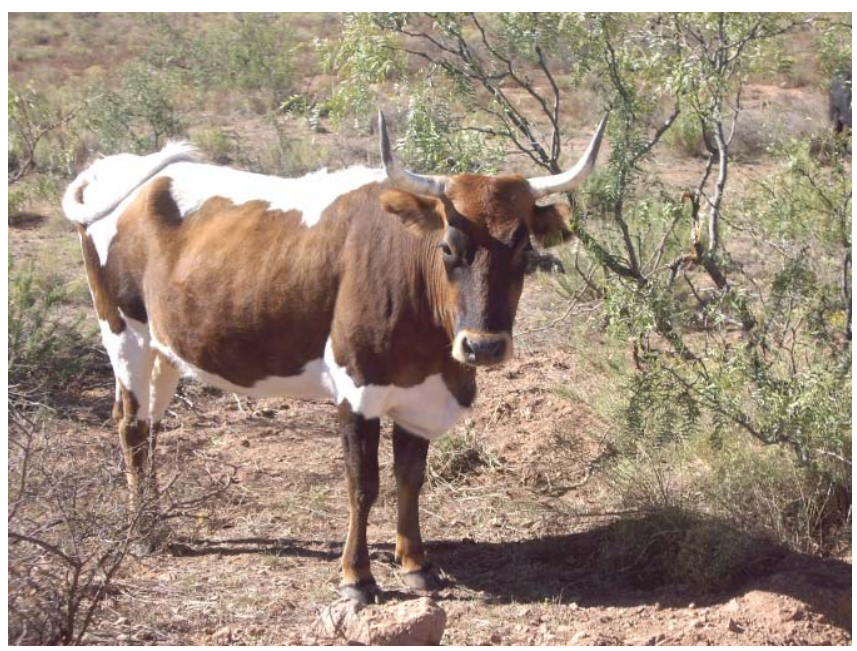

Rodeo cattle. Photo by Alfonso Tarin Bustamante.

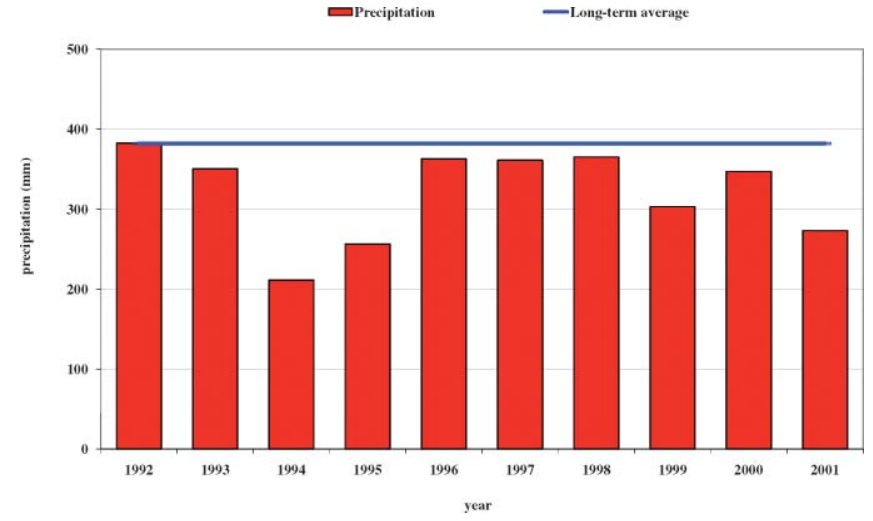

Figure 3. Precipitation (1992-2001) in Chihuahua, México, compared to the long-term average.

Because of its geographic position, drought in Chihuahua is common; however, the drought cycle of the 1990s extended for more than a decade without relief. The drought followed a wet winter and spring in 1992; since then, precipitation has been erratic and well below the long-term average (Fig. 3) with the least amount of precipitation occurring during 1994 and 1995. The cumulative effect of the decade-long drought affected the ecology and productivity of rangelands as well as the state's cattle industry. Drought can be defined by 1) low recorded precipitation amounts, 2) reduction in agricultural production due to low soil water conditions, 3) reduction in surface and underground water storage, and/or 4) reduction in society's well-being due to water shortages. ${ }^{4}$ The present drought cycle in Chihuahua meets all four of these criteria.

The economic and ecological impact of drought on the Chihuahuan beef industry is difficult to estimate due to the complexity among multiple interacting factors. ${ }^{4}$ In this article we attempt to unravel this complexity and illustrate the effects of a decade of drought on Chihuahua's rangelands and beef cattle production sector using published technical reports, personal experiences, direct observations, and comments shared with us by the state's ranching community.

\section{Ecological Impact}

A broad and detailed study describing rangeland conditions in Chihuahua was conducted in 1978 by the Technical Commission for Regional Determination of Rangeland Stocking Rates. ${ }^{5}$ This federal agency identified 18 natural vegetation types. The study also estimated stocking rates for each vegetation type. The general classification of grasslands includes seven vegetation types with stocking rates ranging from 8.5 ha to 21.0 ha (21-52 acres) per animal unit (au). Six shrubland vegetation types were classified with stocking rates ranging from $13.5 \mathrm{ha} \cdot \mathrm{au}^{-1}$ to $60.0 \mathrm{ha} \cdot \mathrm{au}^{-1}$ (33-148 acres $\left.\cdot \mathrm{au}^{-1}\right)$. Temperate forests include four vegetation types with stocking rates ranging from $16 \mathrm{ha} \cdot \mathrm{au}^{-1}$ to 
$28 \mathrm{ha} \cdot \mathrm{au}^{-1}\left(40-69 \mathrm{acres} \cdot \mathrm{au}^{-1}\right)$, and the rainforest has one vegetation type with an average stocking rate of $10.1 \mathrm{ha} \cdot \mathrm{au}^{-1}$ $\left(25\right.$ acres $\left.^{\cdot} \mathrm{au}^{-1}\right) .^{5}$ During the drought, Melgoza et al. ${ }^{6}$ surveyed 21 ranches located in areas representing each vegetation type in the arid and semiarid portions of the state. They reported a reduction in forage production in four vegetation types. Biomass production declined from 1978 to 1996 in shrublands and grasslands by $52 \%$ and $42 \%$, respectively. Recurrent and long lasting drought cycles coupled with mismanagement during both the drought and postdrought periods were determined to be the major causes of the deteriorated conditions they observed. As mentioned by Sosebee and Wan, ${ }^{7}$ grazing per se does not necessarily cause significant changes in vegetation. But inappropriate grazing practices, exacerbated by the detrimental impacts of drought on rangelands, drastically modified community species composition and ecosystem function. ${ }^{8}$

Mismanagement of native forage resources due to improper grazing practices, both during and after drought, has greatly multiplied the negative ecological impacts of drought on Chihuahua's rangelands. In some cases, rangelands are still being overstocked and cattle maintained using supplemental feeds during forage shortages. In other cases stocking rates were adjusted.

Leaving a proper amount of herbage standing crop during dormancy is a key management practice necessary to maintain healthy rangelands. This strategy has greater importance during drought. ${ }^{7}$ Deferring, limiting, or avoiding defoliation of native grasses during the postreproductive stage until dormancy allows for tiller recruitment plus energy storage necessary for overwintering and regrowth the following growing season. Failure to apply basic range management practices during the recent drought cycle is a likely reason for the dramatic changes in Chihuahua's rangelands. For example, in semiarid and arid ecosystems it is evident that mesquite and creosote bush have expanded into areas that were grasslands prior to the drought beginning in 1992. Annual grasses and forbs with low forage value have replaced perennial grasses within many of these ecosystems. A reduction in perennial grass crown cover and presence of large patches of dead plants is a common occurrence. Consequently, lack of soil cover accelerates soil erosion by convectional thunderstorms (high intensive rainstorms) typical of this region, and strong winds that occur during the autumn and early spring. Cattle tracks become deep gullies and dust storms increase its frequency and intensity.

The other two ecological regions, the high plains and mountains, underwent similar changes in plant community structure and accelerated erosion. In addition, woody plants such as junipers, pinion pines, and manzanita increased in density and total cover. Once permanent streams and springs have dried up or have intermittent flows. Today, well organized, informed, and innovative ranchers are implementing management practices to cope and mitigate the negative effects of drought on their properties. Many private ranchers are adjusting stocking rates, implementing grazing systems, and employing methods to reduce, or even stop, soil erosion. However, most communal lands remain overstocked and are continuously grazed, a combination certain to perpetuate degraded range conditions. Hardin in his 1968 paper $^{9}$ attempts to explain the different outcomes between private and communal ownership. First, if there are no personal costs or enforced regulations, shared resources will be used excessively, and when depleted, continued overuse will ultimately ensue, resulting in continued deterioration and eventual destruction of the resource. ${ }^{10}$ Secondly, when the numbers of producers who can participate are not limited, more labor and capital are used than is necessary to achieve a required level of output. ${ }^{10}$ This is currently happening to most communal lands in Chihuahua, as evidenced by their extremely overgrazed conditions and resulting low productivity. ${ }^{10}$

The damage to soil, vegetation, and ecosystem processes are easily seen on most of Chihuahua's rangelands. It is the result of cumulative effects resulting from a decade of drought and improper grazing that has lessened the potential of rangelands to support livestock and wildlife over the long-term. Correcting this trend will take time, many wet years, and perhaps more importantly, a better understanding of ecosystem properties from plant morphology and physiology to overall landscape functioning. Knowledge acquired and used by ranchers and land managers about plant carbohydrate production and energy storage, localization and function of growing points, and vulnerability to defoliation, will help correct the current trend. Additionally, understanding the importance of proper livestock stocking rates, forage utilization, and season of use (when to protect grasses from defoliation and the amount of residual herbage left through dormancy), then applying this knowledge will prevent further damage to our rangelands.

\section{Economic Impact}

Besides the extended drought cycle and mismanagement that diminished the forage potential of Chihuahua rangelands, the financial instability in the Mexican economy during 1995 and 1996 worsened the already precarious financial situation of most beef cattle operations. Financial turmoil that brought currency devaluation, high interest and inflation rates, along with high-cost loans, affected the ranching sector. As a result of this financial situation, operational costs increased in terms of supplemental feed, fuels, and interest rates. Additionally, cattle prices were lower in US markets during this period, which restricted income potential. The combination of these factors financially weakened cattle operations in Chihuahua and the ability of ranchers to meet their financial obligations. The result drove many ranchers to bankruptcy.

The Chihuahua cattle industry was also affected by a large decrease in beef cattle inventories. Numbers dropped about 60\% during the decade of the 1990s (Fig. 4) after 


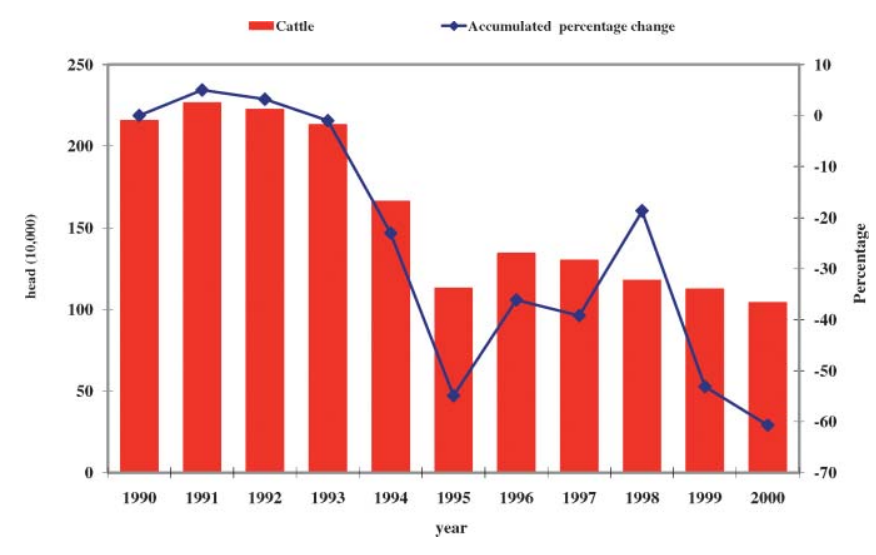

Figure 4. Cattle inventory in Chihuahua, México, and cumulative percent change from 1990 to 2000.

remaining almost constant during the first 4 yr (1990-1993). The inventory began decreasing in 1994 and continued in a downward trend into 1995, decreasing cattle numbers $54 \%$ during both years. This reduction in livestock numbers occurred during the driest years (Fig. 3). Along with the reduction in cattle inventory was an increase in beef cattle numbers exported to US markets. During the cattle cycle of 1994-1995, cattle exports increased 63\% when compared to previous years (Fig. 5). Part of the increase in exports included heifers. During 1994-1995 the Mexican government allowed exportation of heifers, a policy intended to help ranchers receive a better price for their heifers. While this action lessened rancher's financial burden, it also accelerated a decline in the base herd. Many ranchers liquidated their cattle inventory because of difficulties maintaining their cattle operations and to cover their financial liabilities.

Ortega-Ochoa ${ }^{11}$ evaluated a cow/calf operation in the semiarid area of Chihuahua from 1993 to 1998. Production and financial variables in the cattle enterprise were analyzed with information provided by the owner. Low precipitation

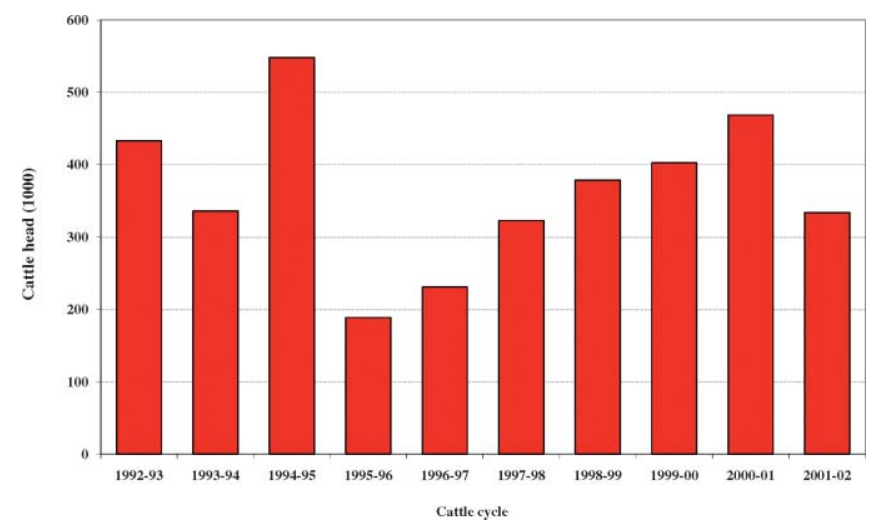

Figure 5. Beef cattle numbers exported from Chihuahua, México, to the US markets per cattle cycle (beginning in September and ending in August).

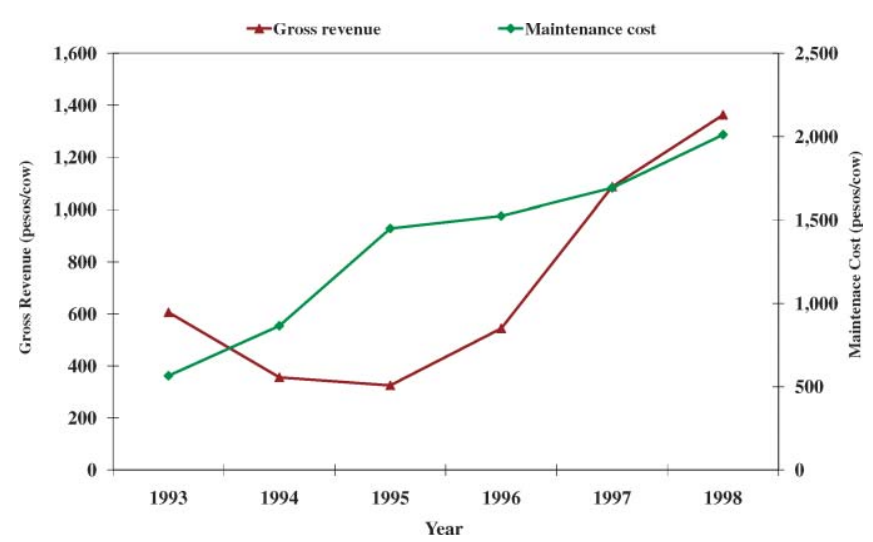

Figure 6. Annual cost of maintaining a cow, and her gross revenue (in pesos) from 1993 to 1998 in a cow/calf enterprise located in a semiarid region of Chihuahua, México.

for three consecutive years decreased rangeland productivity and productivity of the base herd. Between 1994 and 1995, the base herd size decreased $62 \%$ largely due to high mortality rates. The cost of maintaining a cow increased from 566 pesos $\cdot \mathrm{cow}^{-1}$ in 1993 to 2,011 pesos $\cdot \mathrm{cow}^{-1}$ in 1998 (Fig. 6). Supplemental feeding represented $60 \%$ and $48 \%$ of these costs in 1993 and 1998, respectively. On the other hand, estimated gross revenue per cow (price obtained for a weaned calf value minus supplemental feed and water

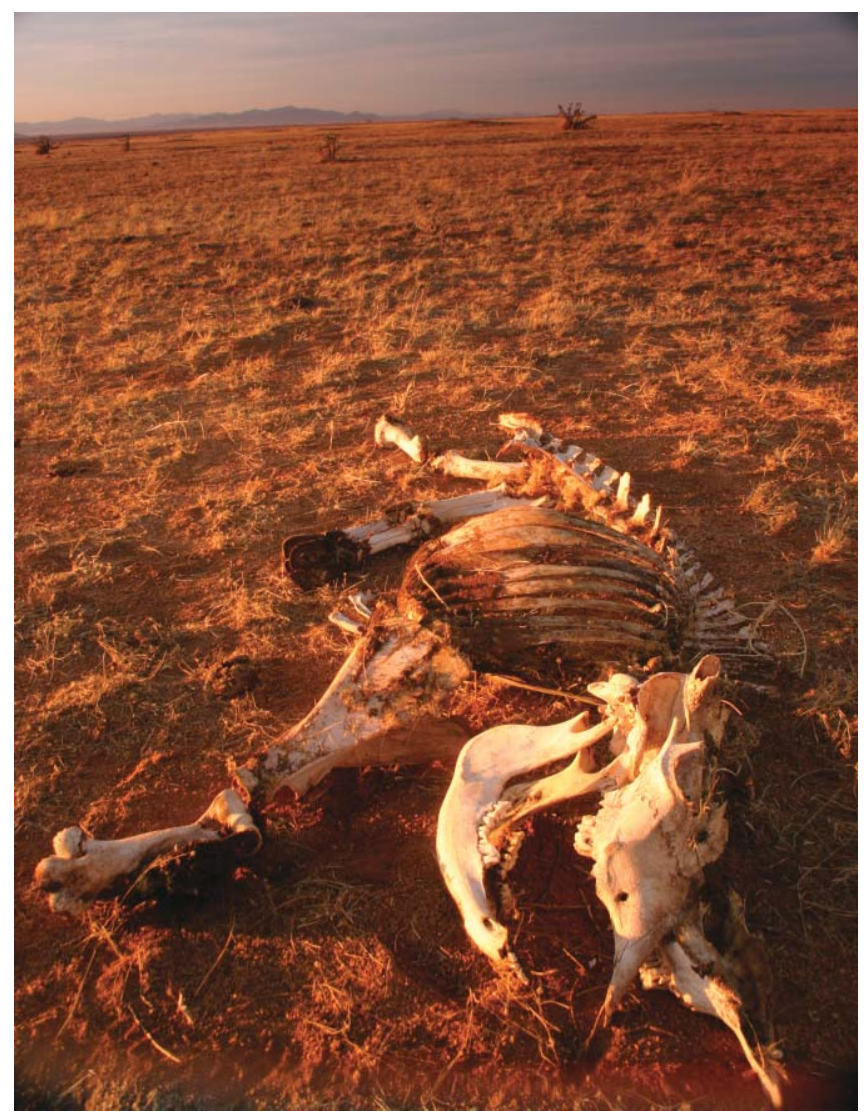

Drought's mortality. Photo by Eduardo Ponce. 
hauling costs) was less than total annual maintenance costs during the years 1994 to 1996 . The cow/calf operation was severely affected by low cattle inventories, low conception rates, high mortality rates, high maintenance costs, and low cattle prices. The situation was worsened by the financial crisis of 1995 and 1996, when interest and inflation rates reached their peak at $40 \%$ and $35 \%$, respectively. ${ }^{12}$ This further reduced profitability by increasing operation costs.

In a more recent study, Martínez-Nevárez surveyed cow/ calf operations in each ecoregion. Martínez then reported that $58 \%$ of weaned calves weighed less than $147 \mathrm{~kg}$ (324 pounds). This represents approximately $5.1 \mathrm{~kg}$ of beef produced per hectare (4.6 pounds $\cdot \mathrm{acre}^{-1}$ ) at a value of 85 pesos (approximate 2000 exchange rate of 8.75 pesos per US dollar). This figure includes cull cows and bulls. The study emphasized that the return on investment was negative in almost all ecological regions evaluated, with the average return on investment being $-5.4 \%$. The primary causes were low weaning rates, weaning weights, and calf prices. The study concluded that $10 \mathrm{yr}$ of drought, and the prevailing unfavorable economic conditions, negatively affected profitability of Chihuahua's cow/calf operations.

Martínez then pointed out that while ranchers have no influence on weather conditions, they can reduce production costs, and improve production efficiency. Meanwhile, the Mexican government must act to stabilize the economy before the livestock sector can attain a degree of certainty necessary for a viable livestock industry.

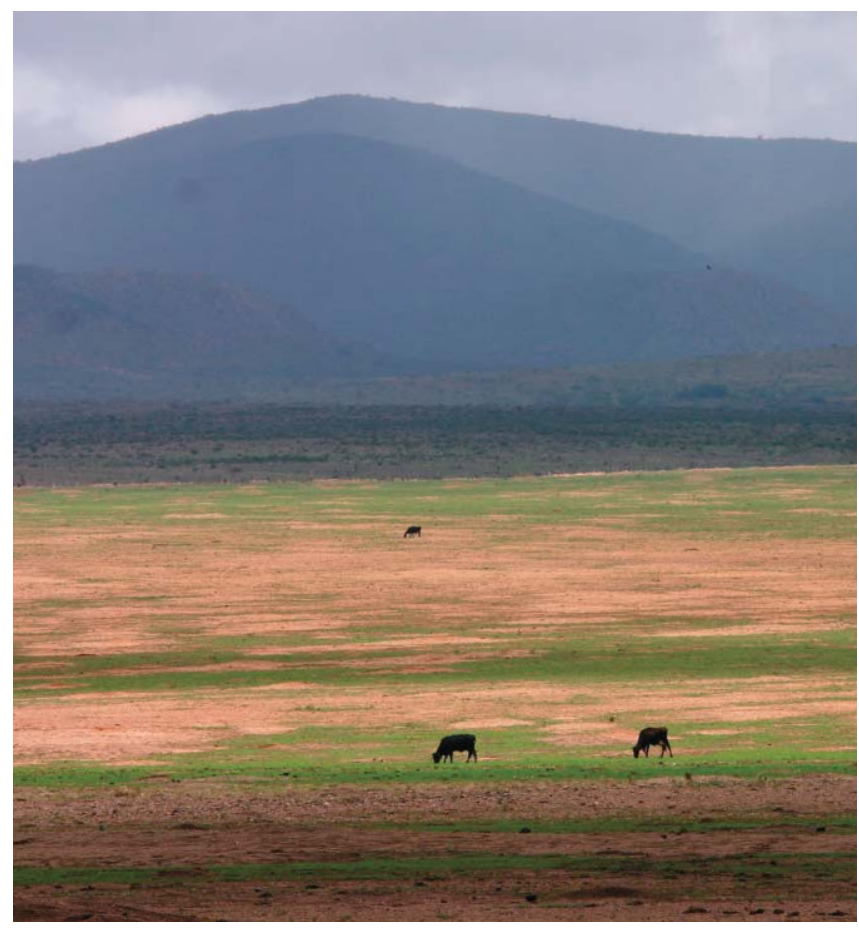

Ejido Casa de Janos. Photo by Eduardo Ponce.

\section{Conclusions}

The ecological impact of drought and livestock mismanagement on Chihuahua's rangelands was severe during the last decade of the twentieth century and into the twenty-first century. The result was significant changes in ecosystem structure and function in every Chihuahuan plant community studied. Long-term effects of this degradation are likely to persist due to soil degradation. Rangeland productivity in some areas fell below levels needed to sustain viable wildlife and livestock populations. A better understanding of native plant growth and responses to drought and grazing are necessary to allow range management professionals, land managers, and ranchers to adequately respond to drought. Furthermore, economic conditions and structure of the beef industry need to be redesigned in a way that allows beef cattle producers to respond to the vagaries of weather and climate.

Financial analyses of individual and state-wide cattle operations and broad state surveys show that a decade of drought harmed Chihuahua's cattle industry. Low prices for beef along with increasing production costs turned cattle operations into nonprofitable enterprises. Adjustments and planning for future droughts is required since long-term data indicate that drought is the rule, and not the exception, for all of Chihuahua's rangelands.

\section{References}

1. Registro Agrario Nacional. 2007. Elaborado por la dirección general de estudios y publicaciones de la procuraduría agraria, con información del Registro Agrario Nacional, 31 de mayo de 2007, México. Available at: http://cuentame.inegi. gob.mx/monografias/informacion/Chih/.

2. Assies, W. 2008. Land tenure and tenure regimes in Mexico: an overview. Journal of Agrarian Change 8(1):33-63.

3. Sosebee, R. E. 2004. Grazing management in preparation for drought and drought recovery. Grazing management workshop; September 2003. Chihuahua, México: Universidad Autónoma de Chihuahua. 78 p.

4. Thurow, T. L., and C. A. Taylor. 1999. Viewpoint: the role of drought in range management. Journal of Range Management 52:413-419.

5. Comisión Técnico Consultiva para la Determinación Regional de los Coeficientes de Agostadero. 1979. Coeficientes de agostadero. Chihuahua, México, D.F.: Secretaría de Agricultura y Recursos Hidráulicos. 685 p.

6. Melgoza, A., M. Royo, A. Baez, and G. Reyes. 1998. Situación de predios ganaderos después de cuatro años de sequía en las zonas áridas y semiáridas de Chihuahua. Chihuahua, México: Instituto Nacional de Investigaciones Forestales y Agropecuarias, Campo Experimental "La Campana," Folleto Técnico No. 4. 23 p.

7. Sosebee, R. E., And C. Wan. 2004. Back to basics: grass growth \& how grasses respond to defoliation. Annual Meeting of the Texas Section-SRM; Kerville, TX, USA. Lubbock, TX, USA: Texas Tech University. 7 p.

8. Fleischner, T. L. 1994. Ecological costs of livestock grazing in western North America. Conservation Biology 8:629-644. 
9. Hardin, G. 1968. Exploring new ethics for survival. New York, NY, USA: Viking Press. 273 p.

10. LaBaume, J. T. 1979. The socio-economics of communal grazing land management: a preliminary case study of the ejido of northern Mexico [PhD Dissertation]. Lubbock, TX, USA: Texas Tech University. 93 p.

11. Ortega-Ochoa, C. 1999. Diagnostico productivo y económico de una empresa ganadera en el Municipio de Camargo, Chihuahua, durante el periodo 1993-1998. Chihuahua, México: Unpublished draft. 8 p.

12. Instituto Nacional de Estadística Geografía e InforMÁtica. 2002. Estadísticas Económicas. Available at: www. inegi.gob.mx/estadisticas/economia/mon_05.html. Accessed August 2002.

13. Martínez-Nevárez, J. 2001. Costos y rentabilidad de la producción de carne bajo condiciones extensivas y costos de producción y rentabilidad de los establos lecheros en el Estado de Chihuahua. Chihuahua, México: Report, Facultad de Zootecnia, Universidad Autónoma de Chihuahua. 71 p.

\section{Additional Reading}

Comisión Nacional del Agua. 2002. Gerencia Estatal Chihuahua. Chihuahua, México: Subgerencia de Administración del Agua. 3 p.

Departamento de Ganadería. 2002. Secretaría de Desarrollo Rural, Chihuahua, México: Gobierno del Estado de Chihuahua. $12 \mathrm{p}$.

Authors are Professor, Range Management (Ortega-Ochoa) and Professor and Dean (Martinez-Nevárez), Facultad de Zootecnia, Universidad Autónoma de Chibuahua, Chibuahua, México; and Associate Professor, Range Management, C.Villalobos@ttu.edu (Villalobos), Professor, Fire Ecology (Britton), and Professor, Plant Ecophysiology (Sosebee), Dept of Natural Resources Management, Texas Tech University, Lubbock, TX 79409, USA. This is Paper T-9-1147-College of Agricultural Sciences and Natural Resources, Texas Tech University. 